\title{
The impact of electronic banking on profitability and market share: Evidence from banking industry
}

\author{
Mohammad Khodaei Valahzaghard ${ }^{a}$ and Elham Bagherzadeh Bilandi $^{\mathbf{b}^{*}}$
}

\begin{abstract}
${ }^{a}$ Assist. Prof. \& Faculty Member, Department of Accounting, School of Management and Human Sciences, Tehran North Branch, Islamic Azad University (IAU), Tehran, Iran

${ }^{b}$ M.Sc. Student, Department of Commercial Management, School of Management and Human Sciences, Tehran North Branch, Islamic Azad University (IAU), Tehran, Iran

C H R O N I C L E

Article history:

Received June 4, 2014

Accepted 29 October 2014

Available online

November 82014

Banking industry

Profitability

Market share

Information technology

A B S T R A C T

This paper presents an empirical investigation to study the effects of electronic banking devices such as automated telling machines (ATM), Point of sales (POS) and Pin Pad on profitability and market share in Iranian banking industry. The population of this study considers the information of 16 banks, five governmental and eleven private, over the period 2007-2012. Using two regression techniques, the study has detected that while Pin Pad may influence on return of assets positively, ATM and POS may not have any meaningful impact on profitability. Moreover, in our survey, none of technological facilities had a meaningful impact on market share but there was a positive and meaningful relationship between bank size and market share.
\end{abstract}

\section{Introduction}

The banking industry is normally based on efficient service delivery and it is always necessary to introduce various services to expedite this process (Tasaki \& Yamakawa, 2011; Lin, 2007). There have been different tools for helping this sector maintain continuous improvement such as automated teller machine (ATM), Point of sales (POS), Pin Pad, etc. (Pantano \& Viassone, 2014) There are also many studies on learning the effects of these components on profitability and market share of banking industry. Although the implementation of ATMs in the U.S. is reaching saturation, ATM deployment still has an increasing trend of use in other parts of the world, such as Australia, China, Canada, Germany, and the United Kingdom. The relationship between information technology (IT) investment and firm performance has been vastly studied, and some researchers have examined the effect of self-service technology (SST) in general and ATMs in particular on a firm's cost efficiency. According to the relative importance of SSTs in the banking industry, therefore Ou et al. (2009) empirically studied the cost efficiency effects on ATMs and reported that ATM investments were associated with positive cost efficiency in the banking industry.

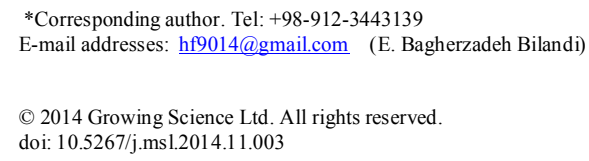


The idea that banks are exploiting customers through their fee-charging activities in an attempt to maximize their profits, has increased interest in detecting the banks that profit most heavily from fees (Tennant \& Sutherland, 2014; Rantos \& Markantonakis, 2014). Scholnick et al. (2008) provided a comprehensive survey of the large and diffuse literature on credit cards, debit cards and ATMs. They explained about many outstanding issues and questions about the pricing, use and substitutability of these payment mechanisms. They examined the pricing of credit cards, the effect of networks on the provision and pricing of ATMs, as well as the tradeoffs that consumers make between various kinds of payment mechanism, including debit cards, credit cards and ATMs. They concluded that point of sale (debit card) and ATM transactions were substitutes and ATM surcharges influenced on point of sale volume, significantly.

Khodaei Valahzaghard and Shakourloo (2013) performed a study on relationship between information technology facilities and performance of banking industry. They studied the effect of five new products namely ATM, POS Machines, PinPad machines, online and swift branches on banking performance indicators including return on assets (ROA), return on equities (ROE) and operating investment return (OIR). They used the information of 19 private and governmental banks, which were active in Iran over the period of 2005-2010. Using some linear regression analysis as well as VAR technique, they studied the effects of the independent variables on bank performance indicators. The results indicated that while there were some weak and positive relationships between three technology indicators including POS, PinPad and online businesses and ROA as well as ROE, there was also a relatively strong and positive relationship between these three independent variables and OIR. In addition, while the results of VAR analysis reported that any reduction on PinPad would reduce OIR but this reduction will disappear after approximately four periods.

\section{The proposed study}

This paper presents an empirical investigation to study the effects of electronic banking on profitability and market share in Iranian banking industry. The proposed study consists of two main hypotheses as well eight sub-hypotheses as follows,

Main hypothesis 1: Electronic banking influences positively on profitability in banking industry.

1. Automated telling machines (ATM) development influences positively on profitability of banking industry.

2. Point of sales (POS) development influences positively on profitability of banking industry.

3. Pin Pad development influences positively on profitability of banking industry.

4. Number of branches (NB) influences positively on profitability of banking industry.

5. Bank size (SIZE) influences positively on profitability of banking industry.

Main hypothesis 2: Electronic banking influences positively on market share (MS) in banking industry.

6. Automated telling machines (ATM) development influences positively on market share of banking industry.

7. Point of sales (POS) development influences positively on market share of banking industry.

8. Pin Pad development influences positively on market share of banking industry.

9. Number of branches (NB) influences positively on market share of banking industry.

10. Bank size (SIZE) influences positively on market share of banking industry.

To examine the hypotheses of this survey, the proposed study considers the following two regression models, 
$R O A_{i, t}=\beta_{0}+\beta_{1} A T M_{i, t}+\beta_{2} P_{O S S_{i, t}}+\beta_{3} P I N_{-} P A D_{i, t}+\beta_{4} \operatorname{Size}_{i, t}+\beta_{5} N B_{i, t}+\varepsilon_{i, t}$

$M S_{i, t}=\beta_{0}+\beta_{1} A T M_{i, t}+\beta_{2} P O S_{i, t}+\beta_{3} P I N_{-} P A D_{i, t}+\beta_{4} \operatorname{Size}_{i, t}+\beta_{5} N B_{i, t}+\varepsilon_{i, t}$

where return on assets (ROA) and market share (MS) are two dependent variables, ATM, POS, Pin Pad are dependent variables and NB and SIZE are control variables. In addition, $\varepsilon_{i, t}$ represents residuals and finally $\beta_{0}$ to $\beta_{5}$ represent coefficients to be estimated. The population of this study considers the information of 16 banks, five governmental and eleven private, over the period 20072012. Table 1 and Fig. 1 show some basic statistics associated with the proposed study.

\section{Table 1}

The summary of some basic statistics

\begin{tabular}{cccccccc}
\hline \multirow{2}{*}{ Statistics } & \multicolumn{3}{c}{ Independent } & \multicolumn{2}{c}{ Dependent } & \multicolumn{2}{c}{ Control variable } \\
& ATM & POS & Pin_Pad & MS & ROA & NB & SIZE \\
\hline Mean & 2.420871 & 3.983425 & 2.637096 & 0.062058 & 0.020392 & 2.568651 & 4.923648 \\
Median & 2.487138 & 4.481271 & 2.792392 & 0.0459 & 0.013 & 2.434569 & 5.048228 \\
Max & 3.603036 & 5.526942 & 4.143577 & 0.228835 & 0.39 & 3.515476 & 5.89725 \\
Min & 0.477121 & 0.69897 & 0.69897 & $1.20 \mathrm{E}-05$ & -0.018 & 0 & 3.522835 \\
Std. Dev. & 0.732574 & 1.31361 & 0.78743 & 0.059463 & 0.041144 & 0.744359 & 0.605635 \\
Skewness & -0.38416 & -1.12761 & -0.46117 & 0.923962 & 7.776517 & -0.49472 & -0.41318 \\
Kurtosis & 2.17701 & 3.019599 & 2.436283 & 2.904196 & 70.11284 & 2.7835 & 2.223719 \\
N & 96 & 96 & 96 & 96 & 96 & 96 & 96 \\
\hline
\end{tabular}
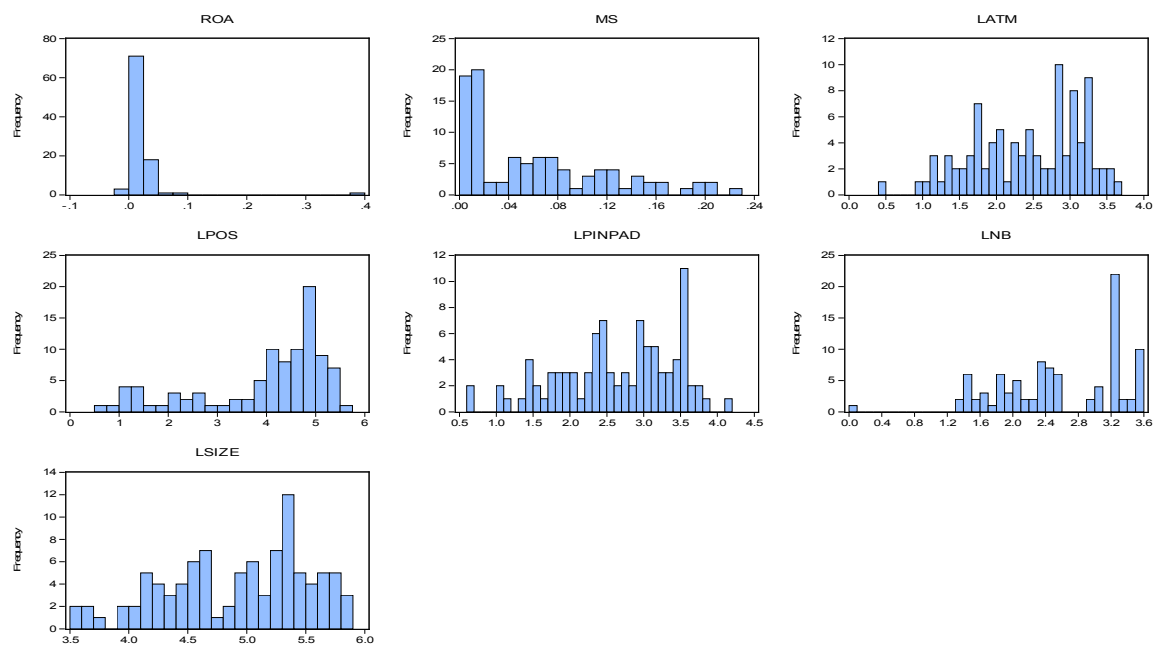

Fig. 1. The summary of some basic statistics

As we can observe from the results of Table 1 and Fig. 1, there are some positive and negative skewness associated with different statistics of the survey. Therefore, they may not follow normal distribution. Table 2 also shows the results of Jarque-Bera test for normality investigation. The results of Table 2 also indicate that some of the components are normally distributed and some not. In this survey, we will use logarithm of the data to convert the data into a more appropriate form of data.

Table 2

The summary of Jarque-Bera test

\begin{tabular}{cccccccc}
\hline \multirow{2}{*}{ Statistics } & \multicolumn{3}{c}{ Independent } & \multicolumn{2}{c}{ Dependent } & \multicolumn{2}{c}{ Control variable } \\
& ATM & POS & Pin_Pad & MS & ROA & NB & SIZE \\
\hline Jarque-Bera & 5.017734 & 20.13382 & 4.625240 & 13.55335 & 18786.37 & 4.060725 & 5.088345 \\
P-value & 0.081360 & 0.000042 & 0.099002 & 0.001140 & 0.000000 & 0.131288 & 0.078538 \\
\hline
\end{tabular}


Next, we have to find out whether the data were stationary or not and this happens through the implementation of Dickey-Fuller (DF) summarized in Table 3 and the results indicate that all data were stationary.

Table 3

The summary of Dickey-Fuller test

\begin{tabular}{cccccccc}
\hline \multirow{2}{*}{ Statistics } & \multicolumn{3}{c}{ Independent } & \multicolumn{2}{c}{ Dependent } & \multicolumn{2}{c}{ Control variable } \\
& ATM & POS & Pin_Pad & $M S$ & ROA & NB & SIZE \\
\hline Jarque-Bera & -28.2284 & -55.5968 & -31.9128 & -52.4726 & -72.9090 & $-6.5 \mathrm{E}+15$ & $-1.2 \mathrm{E}+14$ \\
P-value & 0.0000 & 0.0000 & 0.0000 & 0.001140 & 0.000000 & 0.131288 & 0.078538 \\
\hline
\end{tabular}

We have also considered correlation between various variables of the survey and, in our survey, we did not find any strong correlation.

\section{The results}

In this section, we present details of our findings on testing the hypotheses of the survey using some regression techniques.

\subsection{The first hypothesis: The effects of electronic banking on ROA}

The first hypothesis of the survey investigate the effects of three variables of ATM, POS and Pin_Pad as well as two control variables, NB and SIZE, on ROA. Table 4 shows the results of our survey.

\section{Table 4}

The summary of testing the first hypothesis

\begin{tabular}{|c|c|c|}
\hline Variable & Statistics & Value \\
\hline \multirow{3}{*}{$C$} & $\beta_{0}$ & 0.076050 \\
\hline & t-student & $(0.980915)$ \\
\hline & P-value & $(0.3298)$ \\
\hline \multirow{3}{*}{ LATM } & $\beta_{1}$ & -0.006174 \\
\hline & t-student & $(-0.521851)$ \\
\hline & $\mathrm{P}$-value & $(0.6033)$ \\
\hline \multirow{3}{*}{$L P O S$} & $\beta_{2}$ & 0.002007 \\
\hline & t-student & $(0.421207)$ \\
\hline & P-value & $(0.6748)$ \\
\hline \multirow{3}{*}{ LPINPAD } & $\beta_{3}$ & 0.011823 \\
\hline & t-student & $(2.218928)$ \\
\hline & P-value & $(0.0296)$ \\
\hline \multirow{3}{*}{$L S I Z E$} & $\beta_{4}$ & -0.033533 \\
\hline & t-student & $(-1.087724)$ \\
\hline & P-value & $(0.2802)$ \\
\hline \multirow{3}{*}{$L N B$} & $\beta_{5}$ & 0.033177 \\
\hline & t-student & $(0.805527)$ \\
\hline & $\mathrm{P}$-value & $(0.4231)$ \\
\hline
\end{tabular}

$\mathrm{F}$-value $=1.774780(0.039927)$ Adjusted R-Square $=0.141518$ Durbin-Watson $=2.43$ Jarque-Bera $=16653.78(0.0000)$

According to the results of Table 4, F-value is meaningful when the level of significance is five percent and Durbin-Watson is within an acceptable level. The adjusted R-Square is equal to 0.14, which means the independent variables could describe approximately $14 \%$ of the changes on dependent variable. As we can observe from the results of t-student values, only the coefficient of PinPad is statistically significant and the effects of other variables cannot be confirmed. 


\subsection{The second hypothesis: The effects of electronic banking on market share}

The second hypothesis of the survey investigate the effects of three variables of ATM, POS and Pin_Pad as well as two control variables, NB and SIZE, on market share. Table 5 demonstrates the results of our survey.

Table 4

The summary of testing the second hypothesis

\begin{tabular}{|c|c|c|}
\hline Variable & Statistics & Value \\
\hline \multirow{3}{*}{$C$} & $\beta_{0}$ & 0.059512 \\
\hline & t-student & $(2.610841)$ \\
\hline & P-value & $(0.0115)$ \\
\hline \multirow{3}{*}{ LATM } & $\beta_{1}$ & -0.001186 \\
\hline & t-student & $(-0.450431)$ \\
\hline & P-value & $(0.6541)$ \\
\hline \multirow{3}{*}{$\angle P O S$} & $\beta_{2}$ & -0.000787 \\
\hline & t-student & $(-0.308351)$ \\
\hline & $\mathrm{P}$-value & $(0.7589)$ \\
\hline \multirow{3}{*}{ LPINPAD } & $\beta_{3}$ & 0.000499 \\
\hline & t-student & $(0.104082)$ \\
\hline & P-value & $(0.9175)$ \\
\hline \multirow{3}{*}{ LSIZE } & $\beta_{4}$ & 0.005825 \\
\hline & t-student & (2.409339) \\
\hline & P-value & $(0.0192)$ \\
\hline \multirow{3}{*}{$L N B$} & $\beta_{5}$ & -0.008291 \\
\hline & t-student & $(-1.333735)$ \\
\hline & $\mathrm{P}$-value & $(0.1875)$ \\
\hline
\end{tabular}

F-value $=436.2814(0.00000)$ Adjusted R-Square $=0.244174$ Durbin-Watson $=2.47$ Jarque-Bera $=26.56498(0.0000)$

According to the results of Table 4, F-value is meaningful when the level of significance is one percent and Durbin-Watson is within an acceptable level. The adjusted R-Square is equal to 0.24, which means the independent variables could describe approximately $24 \%$ of the changes on dependent variable. As we can observe from the results of t-student values, only the coefficient of SIZE is statistically significant and the effects of other variables cannot be confirmed.

\section{Conclusion}

In today's world, it is not possible to do many transactions without using the recent advances of technology. Many people may transfer money using ATM, Pin Pad, POS, etc. In this paper, we have presented an empirical investigation to study the effects of ATM, Pin Pad, POS on profitability as well as market share of banking industry in Iran. Using two regression techniques, the study has detected that while Pin Pad may influence on return of assets positively, ATM and POS may not have any meaningful impact on profitability. Moreover, in our survey, none of technological facilities had a meaningful impact on market share but there was a positive and meaningful relationship between size and market share in our survey.

\section{Acknowledgement}

The authors would like to thank the anonymous referees for constructive comments on earlier version of this paper.

\section{References}

Ou, C. S., Hung, S. Y., Yen, D. C., \& Liu, F. C. (2009). Impact of ATM intensity on cost efficiency: An empirical evaluation in Taiwan. Information \& Management, 46(8), 442-447. 
Lin, B. W. (2007). Information technology capability and value creation: Evidence from the US banking industry. Technology in Society, 29(1), 93-106.

Pantano, E., \& Viassone, M. (2014). Demand pull and technology push perspective in technologybased innovations for the points of sale: The retailers evaluation. Journal of Retailing and Consumer Services, 21(1), 43-47.

Rantos, K., \& Markantonakis, K. (2014). Analysis of Potential Vulnerabilities in Payment Terminals. In Secure Smart Embedded Devices, Platforms and Applications (pp. 311-333). Springer New York.

Scholnick, B., Massoud, N., Saunders, A., Carbo-Valverde, S., \& Rodríguez-Fernández, F. (2008). The economics of credit cards, debit cards and ATMs: A survey and some new evidence. Journal of Banking \& Finance, 32(8), 1468-1483.

Tasaki, T., \& Yamakawa, H. (2011). An estimation of the effectiveness of waste prevention by using point-of-sales (POS) data-The case of refills for shampoo and hair conditioner in Japan. Resources, Conservation and Recycling, 57, 61-66.

Tennant, D., \& Sutherland, R. (2014). What types of banks profit most from fees charged? A crosscountry examination of bank-specific and country-level determinants. Journal of Banking \& Finance, 49, 178-190.

Khodaei Valahzaghard, M., \& Shakourloo, A. (2013). A study on relationship between information technology facilities and performance of banking industry. Management Science Letters, 3(3), 833-838. 